\title{
Phytoprotection
}

\section{Response of maize inbred lines to two European corn borer (Ostrinia nubilalis) strains in Canada}

\author{
M. Hudon, R.E. Pitblado, R.I. Hamilton, G. Bourgeois, S. Kuzir et R. Girgis
}

Volume 72, numéro 2, 1991

URI : https://id.erudit.org/iderudit/706005ar

DOI : https://doi.org/10.7202/706005ar

Aller au sommaire du numéro

Éditeur(s)

Société de protection des plantes du Québec (SPPQ)1

ISSN

0031-9511 (imprimé)

1710-1603 (numérique)

Découvrir la revue

Citer cet article

Hudon, M., Pitblado, R., Hamilton, R., Bourgeois, G., Kuzir, S. \& Girgis, R. (1991). Response of maize inbred lines to two European corn borer (Ostrinia nubilalis) strains in Canada. Phytoprotection, 72(2), 69-76.

https://doi.org/10.7202/706005ar
Résumé de l'article

Six lignées de maïs-grain (CM47, A619, F2, CM107, CM7 et A654) ont été évaluées en 1986 et 1987 dans quatre localités de l'Ontario et du Québec pour leur résistance à des infestations artificielles de la pyrale du maïs, Ostrinia nubilalis, de la race univoltine et de la première génération de la race bivoltine. Trois critères ont été utilisés: la criblure du feuillage, les dégâts totaux des plantes à la récolte, et le rapport longueur des galeries creusées par les chenilles dans les tiges sur la hauteur des plantes. Des interactions importantes ont été observées pour les critères utilisés entre les années et localités, mais la réaction des lignées de maïs a été plutôt constante. Pour tous les critères, la race univoltine a souvent causé, d'une façon significative, plus de dégâts aux plantes que la race bivoltine. En général, la lignée A619 a démontré le plus de résistance-tolérance tout en conservant une bonne tenue des tiges jusqu'à la récolte. On aurait avantage à utiliser la race univoltine dans les programmes d'amélioration génétique du maïs pour sa résistance à la pyrale. 


\title{
Response of maize inbred lines to two European corn borer (Ostrinia nubilalis) strains in Canada
}

\author{
M. Hudon \\ Research Station, Agriculture Canada, 430 Gouin Blvd., Saint-Jean-sur-Richelieu, \\ Québec, Canada J3B 3E6. Contribution No. 335/91.09.01R
}

R.E. Pitblado

Ridgetown College of Agricultural Technology, Ridgetown, Ontario, Canada NOP 2 CO

\author{
R.I. Hamilton \\ Plant Research Centre, Agriculture Canada, Forage Building \#12, Ottawa, \\ Ontario, Canada K1A 0C6
}

\author{
G. Bourgeois \\ Research Station, Agriculture Canada, 430 Gouin Blvd., Saint-Jean-sur-Richelieu, \\ Québec, Canada J3B 3E6
}

\section{S. Kuzir}

King Agro Inc., Chatham, Ontario, Canada N7M 5L6

\author{
R. Girgis \\ United Co-operatives of Ontario (UCO), Chatham, Ontario, Canada N7M $5 R 9$
}

(Received 1991-03-19; accepted 1991-09-16)

In 1986 and 1987, six maize inbred lines (CM47, A619, F2, CM107, CM7, and A654) were evaluated at four locations across Ontario and Québec for their resistance to artificially infested univoltine and $1^{\text {st }}$ generation bivoltine strains of the European corn borer, Ostrinia nubilalis. Three criteria were used: leaf feeding, total plant damage at harvest and length of tunnels/plant height ratio. Substantial interactions in borer damage measurements were observed between locations and years, but inbred reaction was relatively consistent. For all criteria, the univoltine strain often caused significantly more damage than the bivoltine borer. In general, A619 had the greatest resistance-tolerance with good standability until harvest. Wherever possible, evaluation of genetic resistance in maize germplasm should be conducted using the univoltine borer strain.

Hudon, M., R.E. Pitblado, R.I. Hamilton, G. Bourgeois, S. Kuzir, and R. Girgis. 1991. Response of maize inbred lines to two European corn borer (Ostrinia nubilalis) strains in Canada. PHYTOPROTECTION 72: 69-76.

Six lignées de maïs-grain (CM47, A619, F2, CM107, CM7 et A654) ont été évaluées en 1986 et 1987 dans quatre localités de l'Ontario et du Québec pour leur résistance à des infestations artificielles de la pyrale du maïs, Ostrinia nubilalis, de la race univoltine et de la première génération de la race bivoltine. Trois critères ont été utilisés: la criblure du feuillage, les dégâts totaux des plantes à la récolte, et le rapport longueur des galeries creusées par les chenilles dans les tiges sur la hauteur des plantes. Des interactions importantes ont été observées pour les critères utilisés entre les années et localités, mais la réaction des lignées de maïs a été plutôt constante. Pour tous les critères, la race univoltine a souvent causé, d'une façon significative, plus de dégâts aux plantes que la race bivoltine. En général, la lignée A619 a démontré le plus de résistance-tolérance tout en conservant une bonne tenue des tiges jusqu'à la récolte. On aurait avantage à utiliser la race univoltine dans les programmes d'amélioration génétique du maïs pour sa résistance à la pyrale.

\section{Introduction}

Host plant resistance studies on the European corn borer (ECB), Ostrinia nubilalis Hüb- ner, have been conducted in the United States for over 60 years (Marston and Dibble 1930) and in Canada, for more than 20 years (Anglade et al. 1972). In studies on the resistance to firstgeneration borers, and those of the univoltine strain, the plants were artificially infested by 
dropping egg-laden disks, or newly-hatched larvae (mixed in corncob grits) into the whorl of the plants prior to stem elongation and tassel emergence (Barry and Chippendale 1988). Guthrie et al. (1984) evaluated resistance of 10 to 25 maize genotypes during a four-year period against the larval feeding of the bivoltine strain of $O$. nubilalis using the artificial infestation method. They concluded that levels of damage varied with seasons and may be less with larvae than with egg masses but were adequate for measuring relative degrees of resistance of the genotypes. They recommended the use of larval infestation for screening germplasm for ECB resistance to $1^{\text {st }}$ and $2^{\text {nd }}$ broods, and the use of egg masses in recurrent selection, economic threshold and insecticide evaluation studies. Although univoltine and bivoltine ECB strains have been used separately to evaluate maize germplasm for resistance, very little information is available on the interaction at the same time and same location between maize plants and ECB strain effects.

There is a large geographic zone between southwestern Ontario's $\left(42^{\circ} \mathrm{N}\right)$ major corn belt and the province of Québec $\left(45^{\circ} \mathrm{N}\right)$ where a cooler short season corn belt has evolved. In southwestern Ontario, there are two distinct geographical populations or strains of ECB distinguished by their response to critical photoperiods for diapause induction and in the time required for diapause termination. This explains the occurrences of two complete generations in the southern portion and only one in the northern portion of this region (McLeod 1976). In Québec, populations are predominantly univoltine but traces of a bivoltine strain began to appear in the southwestern part of the province during the mid to late 1970s (Martel and Hudon 1976; McLeod et al. 1979). McLeod (1978) has demonstrated that ECB growth rate was female sex-linked while diapause incidence was male sex-linked.

The objective of the present study was to evaluate at the same time the effects of artificial infestations of the univoltine and bivoltine strains of $O$. nubilalis on six maize inbred lines in the two major corn belts of Canada.

\section{Materials and methods}

In 1986 and 1987, four locations were selected to evaluate the effect of three ECB infestation treatments on six inbred lines. Two sites are located in short-season growing areas (SaintJean-sur-Richelieu in Québec and Ottawa in Ontario) with normally 2700 corn heat units $(\mathrm{CHU})$ where the univoltine strain borer naturally predominates. The other two locations (Chatham and Ridgetown in southwestern Ontario) are long-season areas with $3200 \mathrm{CHU}$, where the bivoltine strain predominates. At the Chatham location, the test was conducted in 1986 by King Agro Inc., while in 1987, the United Co-operatives of Ontario conducted the trial. At the Ridgetown location, the test was conducted by the Ridgetown College of Agricultural Technology. In Ottawa, the test was conducted by the Plant Research Centre of Agriculture Canada and in Saint-Jean-surRichelieu by the Research Station of Agriculture Canada. At each location, a split-splot experimental design with four blocks was used. The main plots consisted of six inbred lines which varied in their flowering and harvest maturity along with their resistance and/or tolerance (total plant damage at harvest) to the ECB (Hudon and Chiang 1985; Hudon et al. 1979): CM7 (early flowering and susceptible), CM47 (early and intermediate), CM 107 (early and resistant), F2 (late and intermediate), A619 (late and resistant) and A654 (late and resistant).

The subplots consisted of three ECB infestation treatments which were artificial infestations of the univoltine and $1^{\text {st }}$ generation of the bivoltine strains of $O$. nubilalis and the check plot which was treated with two applications of granular carbofuran (Furadan $10 \mathrm{G})$ at $1.1 \mathrm{~kg}$ a.i./ha at 2 -week intervals during the egg laying period to assure an insect-free check plot. In each plot, 20 consecutive plants were selected for observations and dissection. Artificial infestations consisted of the deposition of four egg masses into the whorl of each plant (ca. 100 eggs) applied at the end of June and early July in two lots of two masses each, at 2-day intervals. No infestation to simulate the presence of a $2^{\text {nd }}$ generation in August was made. ECB egg masses were obtained according to the rearing technique of Guthrie (\$971) and distributed from Saint-Jean-sur--Richelieu (univoltine) and Ridgetown (bivoltine). Each experimental unit consisted of a single row, $8 \mathrm{~m}$ long, spaced $0.9 \mathrm{~m}$ apart and planted in early May at a rate of 61775 plants/ha. 
Plants were rated for ECB leaf feeding (LF) approximately four weeks after the last egg mass deposition for each borer treatment using a 9-class visual rating ( $1=$ no damage, to 9 = extensive damage) (Guthrie et al. 1960), and for total plant damage (PD) and breakage at harvest using a 10-class visual rating $(1=$ no breakage, to $10=$ plants broken below the ear), as described by Hudon et al.(1979). Plant height was recorded at tasselling in July. After harvest, all stalks within each plot were dissected and the ECB infestation determined by counting cavities and measuring their cumulative length in $\mathrm{cm}$. The criterion tunnels/plant height ratio (TPHR) is the total length of tunnels in $\mathrm{cm}$ in a plant divided by its height; it is considered a reliable criterion for evaluating univoltine ECB damage and resistance and/or tolerance of a maize plant (Hudon and Chiang 1991). For each criterion observed, the mean of the data obtained for the number of plants harvested in each plot were analyzed with an analysis of variance (ANOVA).

\section{Results and discussion}

The response of ECB infestation treatments across the various inbred lines were evaluated under three criteria: LF, PD and TPHR. The criterion length of tunnels is not presented because it is highly correlated $(r=0.96)$ with TPHR and this ratio includes the size of the plant. Since PD ratings are more dependent on the locations and are not correlated with LF ratings (Anglade and cooperators 1973; Hudon and Chiang 1991), the present results (LF and PD ratings) are discussed for each location. The ANOVA for each variable detected significant differences between years tested, inbred lines and borer infestation treatments (Tables 1 and 2). Significant interactions with locations and with years are observed when the data are pooled for all locations and years. When analyzed for each location, the interactions of inbreds with years, and borer infestation treatments with years are significant at the 0.05 level in most cases (Table 1). The interactions of inbreds with borer infestation treatments are generally not significant, but with a few exceptions. In such cases, the interaction is much less significant than the ECB treatment or inbred line. When analysed for each location and year, this last interaction is generally not significant.
Leaf feeding ratings. Normally, LF ratings should not differ much between the two races since active borer feeding on maize plants is normally done at the end of June for the bivoltine strain and early part of July for the univoltine, when plants are normally at the whorl stage. During the two years, LF ratings which rank the levels of host plant resistance to $O$. nubilalis are low (Table 3). As reported by Anglade and cooperators (1973), with early maize germplasm having differences in the number of whorl leaves and their rate of unrolling according to the flowering maturity of the inbred line, LF rating information should be complemented with other evaluating criteria such as PD ratings at harvest. Significant differences in LF ratings between borer infestation treatments are observed at all locations, except Ridgetown. At Chatham and Saint-Jean-sur-Richelieu, the univoltine borer significantly causes more damage than the bivoltine strain and the check plants, and the bivoltine borer significantly causes more damage than the check (Table 3 ). In Ottawa, the races are not significantly different.

In general, the different resistance levels of the inbred lines to $O$. nubilalis as reported previously by Hudon and Chiang $(1975,1985)$ and Hudon et al.(1979) (i.e. some inbreds being more resistant to LF while others are more tolerant to PD at harvest) were observed in most locations (Tables 3 and 4). Significant differences in LF ratings between the inbreds are observed only at the locations where the univoltine borer is naturally present, Saint-Jeansur-Richelieu and Ottawa(Tables 1 and 2), and A619 remains in general, the least infested, and A654 and CM107 having the greatest damage (Table 3).

Plant damage ratings. Significant differences between ECB infestation treatments are observed at all locations (Tables 1 and 2). It should be noted that the races are not significantly different at Chatham and Ridgetown, where the bivoltine borer is naturally present (Table 4), but are significantly different at SaintJean-sur-Richelieu and Ottawa, where the univoltine population naturally predominates (Table 4). The univoltine borer, without any metamorphosis during the growing season, significantly caused more stalk breakage at those two locations. Similar observations were made in the early 60's by Neiswander (1962) when he stated that injury from the first generation of the 


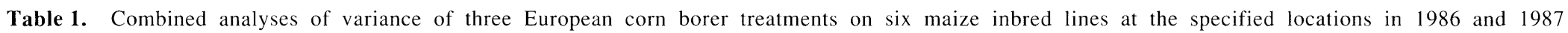

\begin{tabular}{|c|c|c|c|c|c|c|c|c|c|c|c|c|c|c|c|c|c|}
\hline \multirow{4}{*}{$\begin{array}{l}\text { Sources of } \\
\text { variance } \\
\text { Years (Y) }\end{array}$} & \multirow{4}{*}{$\begin{array}{c}\begin{array}{c}\text { Degrees } \\
\text { of } \\
\text { freedom }\end{array} \\
1\end{array}$} & \multicolumn{16}{|c|}{$F$ values } \\
\hline & & \multicolumn{4}{|c|}{ Leaf feeding } & \multicolumn{5}{|c|}{ Plant damage } & \multicolumn{7}{|c|}{ Tunnels/plant height ratio } \\
\hline & & \multicolumn{2}{|c|}{$\begin{array}{c}\text { Saint-Jean- } \\
\text { sur- } \\
\text { Richelieu }\end{array}$} & \multicolumn{2}{|c|}{ Ottawa } & \multicolumn{2}{|c|}{ Chatham } & \multicolumn{2}{|c|}{$\begin{array}{c}\text { Saint-Jean- } \\
\text { sur- } \\
\text { Richelieu }\end{array}$} & Ridgetown & Chatham & \multicolumn{3}{|c|}{$\begin{array}{c}\text { Saint-Jean- } \\
\text { sur- } \\
\text { Richelieu }\end{array}$} & \multicolumn{2}{|l|}{ Ottawa } & Ridgetown \\
\hline & & 5.91 & & 32.93 & $*$ & 79.17 & $* *$ & 3.63 & & 0.54 & 358.67 & $* * *$ & $23.40 *$ & & 174.27 & $* * *$ & 0.00 \\
\hline Blocks (B) & 3 & 2.27 & & 0.72 & & 0.59 & & 0.29 & & 0.65 & 0.57 & & 0.49 & & 0.15 & & 0.70 \\
\hline Main plot error & 3 & & & & & & & & & & & & & & & & \\
\hline Inbred lines (I) & 5 & 15.83 & $* * *$ & 6.49 & $* * *$ & 3.95 & $* *$ & 66.16 & $* * *$ & $23.55 * * *$ & 4.06 & $* *$ & $12.16 *$ & $* * *$ & 2.70 & $*$ & $2.56 *$ \\
\hline I $x Y$ & 5 & 3.21 & $*$ & 2.72 & * & 10.44 & $* * *$ & 7.73 & $* * *$ & 0.78 & 4.82 & $* *$ & $3.11 *$ & & 1.67 & & 2.17 \\
\hline Subplot error & 30 & & & & & & & & & & & & & & & & \\
\hline ECB treatments $(\mathrm{T})$ & 2 & 274.82 & $* * *$ & 23.15 & $* * *$ & 43.03 & $* * *$ & 24.74 & $* * *$ & $5.92 * *$ & 4.41 & * & 71.66 & $* * *$ & 20.97 & $* * *$ & 0.04 \\
\hline$T \times Y$ & 2 & 24.15 & $* * *$ & 12.35 & $* * *$ & 23.39 & $* * *$ & 4.67 & $*$ & 1.34 & 0.55 & & 9.82 & $* * *$ & 9.39 & $* * *$ & 1.08 \\
\hline$T \times I$ & 10 & 5.43 & $* * *$ & 2.21 & * & 1.91 & & 2.01 & & $2.52 *$ & 0.85 & & 2.54 & & 0.92 & & 0.97 \\
\hline $\mathrm{T} \times \mathrm{Y} \times \mathrm{I}$ & 10 & 2.38 & $*$ & 2.21 & $*$ & 2.35 & & 1.71 & & 0.56 & 0.72 & & 1.24 & & 0.66 & & 1.08 \\
\hline Sub-subplot error & 72 & & & & & & & & & & & & & & & & \\
\hline TOTAL & 143 & & & & & & & & & & & & & & & & \\
\hline
\end{tabular}

$*, * *, * * *$ : Significant at the $0.05,0.01$, and 0.001 levels, respectively. 
Table 2. Analyses of variance of three European corn borer treatments on six maize inbred lines at the specified locations in 1987

\begin{tabular}{lcccc}
\hline & \multirow{2}{*}{$\begin{array}{c}\text { Degrees } \\
\text { of } \\
\text { Sources of } \\
\text { variance }\end{array}$} & \multicolumn{2}{c}{$F$ values } \\
\cline { 3 - 4 } & freedom & Chatham & Ridgetown & Plant damage \\
\hline Block $(B)$ & 3 & 0.63 & 0.69 & Ottawa \\
Inbred lines (I) & 5 & 2.81 & 0.52 & 0.47 \\
Main plot error & 15 & & & $11.99 * * *$ \\
ECB treatments (T) & 2 & $10.80 * * *$ & 2.44 & $7.52 * *$ \\
T x I & 10 & 1.92 & 0.63 & 1.03 \\
Subplot error & 36 & & & \\
TOTAL & 71 & & & \\
\hline
\end{tabular}

$* * * * *$ : Significant at the 0.01 , and 0.001 levels, respectively.

bivoltine strain in Ohio was much less than that formerly caused by the first observed singlegeneration borer that invaded the State in the early 20 's.

Significant differences between the inbreds are observed at all locations (Tables 1 and 2). In most locations, the inbred A619 is among the most resistant and CM47 and CM7 among the most susceptible (Table 4). There were some variations between locations, some inbreds being resistant/tolerant in one area, others becoming susceptible in that same area. However, A619 has been tested at Saint-Jean-sur-Richelieu against $O$. nubilalis during seven seasons (Hudon and Chiang 1985; Hudon et al. 1979) and was found in the present study resistant to leaf feeding and tolerant to stalk breakage at harvest in most locations (Tables 3 and 4). This line is among the public inbreds most widely used as a base of maize germplasm in United States (Zuber 1975) and was selected as the standard resistant for the group of intermediatelate inbreds in the ECB cooperative project of

Table 3. Means of leaf feeding (LF) ratings for three European corn borer (ECB) infestation treatments on six maize inbred lines at four locations in 1986 and 1987

\begin{tabular}{|c|c|c|c|c|c|c|}
\hline \multirow[b]{3}{*}{ Treatments } & \multicolumn{6}{|c|}{ Leaf feeding ratings ${ }^{\S}$} \\
\hline & \multirow{2}{*}{$\begin{array}{c}\text { Chatham } \\
1987\end{array}$} & \multirow{2}{*}{$\begin{array}{c}\text { Ridgetown } \\
1987\end{array}$} & \multicolumn{2}{|c|}{$\begin{array}{l}\text { Saint-Jean- } \\
\text { sur-Richelieu }\end{array}$} & \multicolumn{2}{|c|}{ Ottawa } \\
\hline & & & 1986 & 1987 & 1986 & 1987 \\
\hline \multicolumn{7}{|c|}{ ECB infestation } \\
\hline Univoltine & $1.6 \mathrm{a}^{\dagger}$ & $1.4 \mathrm{a}$ & $3.3 \mathrm{a}$ & $2.5 \mathrm{a}$ & $2.3 \mathrm{a}$ & $1.2 \mathrm{a}$ \\
\hline Bivoltine & $1.3 \mathrm{~b}$ & $1.9 \mathrm{a}$ & $1.8 \mathrm{~b}$ & $2.0 \mathrm{~b}$ & $2.2 \mathrm{a}$ & $1.2 \mathrm{a}$ \\
\hline Check & $1.1 \mathrm{c}$ & $2.1 \mathrm{a}$ & $1.1 \mathrm{c}$ & $1.2 \mathrm{c}$ & $1.5 \mathrm{~b}$ & $1.1 \mathrm{a}$ \\
\hline \multicolumn{7}{|l|}{ Inbred lines } \\
\hline A619 & $1.0 \mathrm{a}$ & $1.6 \mathrm{a}$ & $1.3 \mathrm{a}$ & $1.6 \mathrm{a}$ & $1.4 \mathrm{a}$ & $1.1 \mathrm{ab}$ \\
\hline $\mathrm{F} 2$ & $1.2 \mathrm{ab}$ & $1.8 \mathrm{a}$ & $2.0 \mathrm{~b}$ & $1.7 \mathrm{ab}$ & $2.1 \mathrm{a}$ & $1.0 \mathrm{a}$ \\
\hline CM47 & $1.2 \mathrm{ab}$ & $2.2 \mathrm{a}$ & $2.1 \mathrm{bc}$ & $2.1 \mathrm{bc}$ & $1.7 \mathrm{a}$ & $1.0 \mathrm{a}$ \\
\hline $\mathrm{CM} 7$ & $1.4 \mathrm{ab}$ & $2.0 \mathrm{a}$ & $2.4 \mathrm{~d}$ & $1.8 \mathrm{ab}$ & $2.0 \mathrm{a}$ & $1.0 \mathrm{a}$ \\
\hline CM107 & $1.6 \mathrm{~b}$ & $1.4 \mathrm{a}$ & $2.3 \mathrm{~cd}$ & $2.1 \mathrm{bc}$ & $2.9 \mathrm{~b}$ & $1.4 \mathrm{bc}$ \\
\hline A654 & $1.6 \mathrm{~b}$ & $2.0 \mathrm{a}$ & $2.4 \mathrm{~d}$ & $2.3 \mathrm{c}$ & $2.0 \mathrm{a}$ & $1.5 \mathrm{c}$ \\
\hline
\end{tabular}

$\S$ LF rating ( $1=$ no damage, to $9=$ extensive damage).

$\div$ Means followed by the same letter in the same column for the ECB infestation treatments and for the inbred lines are not significantly different at $P>0.05$ (Waller-Duncan K-ratio $t$-test). 
IWGO (International Working Group on $O s$ trinia).

Tunnels/plant height ratios. Significant differences between ECB infestation treatments are observed at all locations, except Ridgetown (Table 1). The univoltine borer produces significantly longer tunnels in the maize stalks than the bivoltine strain, at those locations (Table 5). At Chatham, in 1986, there are no significant differences, but similar trends are observed. In Ottawa and in Saint-Jean-sur-Richelieu (1987), significant differences are observed between the ECB infestation treatments. In most locations, the inbred A619 remains among the most resistant/tolerant (Table 5). There are for SaintJean-sur-Richelieu a positive correlation significant at the $1 \%$ level between PD ratings and TPHR $(r=0.560)$ and for the overall locations $(r=0.240)$ for both years.

It is recognized that mixed ECB populations occupy much of the North American continent differing in diapause characteristics, host plant attraction and morphology (Chiang et al. 1970; Kim et al. 1967; Mutu- ura and Munroe 1970; Showers 1981). Differences among biotypes (borer races) in voltinism persist in identical environments and are known to have a strong genetic basis involving sex-linked non-dominant inheritance (Showers 1981). In the present study, the univoltine borer performed in a similar fashion in southwestern Ontario as in its native short-season habitat of Ottawa and Saint-Jean-sur-Richelieu regions. There were no observation of empty pupal cases found in the maize stalks which may indicate that the bivoltine borer within a short-season habitat did not suffer any metamorphosis.

It is concluded that over a period of two years, at four locations and based on the evaluation of three criteria for resistance, the univoltine borer often caused more plant damage than the bivoltine strain, and A619 remained the least infested inbred with good standability until harvest. This last characteristic becomes particularly important with mechanical harvesting. Wherever possible, the evaluation of maize germplasm for genetic resistance, may be best conducted using the univoltine strain of $O$. nubilalis.

Table 4. Means of total plant damage (PD) ratings at harvest for three European corn borer (ECB) infestation treatments on six maize inbred lines at four locations in 1986 and 1987

\begin{tabular}{|c|c|c|c|c|c|c|c|}
\hline \multirow[b]{3}{*}{ Treatments } & \multicolumn{7}{|c|}{ Total plant damage ratings } \\
\hline & \multicolumn{2}{|c|}{ Chatham } & \multicolumn{2}{|c|}{ Ridgetown } & \multicolumn{2}{|c|}{$\begin{array}{c}\text { Saint-Jean- } \\
\text { sur-Richelieu }\end{array}$} & \multirow{2}{*}{$\begin{array}{l}\text { Ottawa } \\
1986\end{array}$} \\
\hline & 1986 & 1987 & 1986 & 1987 & 1986 & 1987 & \\
\hline \multicolumn{8}{|c|}{$E C B$ infestation } \\
\hline Univoltine & $3.3 \mathrm{a}^{\dagger}$ & 0.9 a & $3.0 \mathrm{a}$ & $3.1 \mathrm{a}$ & $2.2 \mathrm{a}$ & $2.0 \mathrm{a}$ & $4.5 \mathrm{a}$ \\
\hline Bivoltine & $3.6 \mathrm{a}$ & $0.7 \mathrm{a}$ & $3.2 \mathrm{a}$ & $3.2 \mathrm{a}$ & $1.8 \mathrm{~b}$ & $1.8 \mathrm{~b}$ & $3.6 \mathrm{~b}$ \\
\hline Check & $1.1 \mathrm{~b}$ & 0.4 a & $1.9 \mathrm{~b}$ & $2.7 \mathrm{a}$ & $1.9 \mathrm{~b}$ & $1.4 \mathrm{c}$ & $3.5 \mathrm{~b}$ \\
\hline \multicolumn{8}{|l|}{ Inbred lines } \\
\hline A 619 & $1.4 \mathrm{a}$ & $0.5 \mathrm{a}$ & $1.6 \mathrm{a}$ & $2.1 \mathrm{a}$ & $1.4 \mathrm{a}$ & $1.2 \mathrm{a}$ & $3.2 \mathrm{ab}$ \\
\hline A 654 & $3.7 \mathrm{c}$ & $0.1 \mathrm{a}$ & $2.0 \mathrm{a}$ & $1.6 \mathrm{a}$ & $1.5 \mathrm{a}$ & $1.5 \mathrm{bc}$ & $2.3 \mathrm{a}$ \\
\hline C M 107 & $2.8 \mathrm{~b}$ & $0.3 \mathrm{a}$ & $1.9 \mathrm{a}$ & $2.2 \mathrm{a}$ & $1.9 \mathrm{~b}$ & $1.4 \mathrm{ab}$ & $3.7 \mathrm{~b}$ \\
\hline $\mathrm{F} 2$ & $3.5 \mathrm{c}$ & 0.4 a & $1.7 \mathrm{a}$ & $2.8 \mathrm{~b}$ & $1.9 \mathrm{~b}$ & $1.6 \mathrm{c}$ & $3.4 \mathrm{~b}$ \\
\hline C M 7 & $2.3 \mathrm{~b}$ & $1.0 \mathrm{ab}$ & $4.3 \mathrm{~b}$ & $4.3 \mathrm{c}$ & $2.8 \mathrm{~d}$ & $2.0 \mathrm{~d}$ & $5.2 \mathrm{c}$ \\
\hline C M 47 & $2.2 \mathrm{~b}$ & $1.9 \mathrm{~b}$ & $4.5 \mathrm{~b}$ & $4.8 \mathrm{c}$ & $2.4 \mathrm{c}$ & $2.6 \mathrm{e}$ & $5.4 \mathrm{c}$ \\
\hline
\end{tabular}

$\$$ PD rating $(1=$ no breakage, to $10=$ plants broken below the ear $)$.

$\uparrow$ Means followed by the same letter in the same column for the ECB infestation treatments and for the inbred lines are not significantly different at $P>0.05$ (Waller-Duncan K-ratio $t$-test). 
Table 5. Means of tunnels/plant height ratio for three European corn borer (ECB) infestation treatments on six maize inbred lines at four locations in 1986 and 1987

Tunnels/plant height ratio

\begin{tabular}{|c|c|c|c|c|c|c|c|c|c|c|}
\hline \multirow[b]{2}{*}{ Treatments } & \multicolumn{3}{|c|}{ Chatham } & \multicolumn{3}{|c|}{ Ridgetown } & \multicolumn{2}{|c|}{$\begin{array}{l}\text { Saint-Jean- } \\
\text { sur-Richelieu }\end{array}$} & \multicolumn{2}{|c|}{ Ottawa } \\
\hline & 1986 & \multicolumn{2}{|c|}{1987} & 1986 & \multicolumn{2}{|l|}{1987} & 1986 & 1987 & 1986 & 1987 \\
\hline \multicolumn{11}{|c|}{$\overline{E C B}$ infestation } \\
\hline Univoltine & $0.097 \mathrm{a}^{\$}$ & 0.019 & $\mathrm{a}$ & $0.030 \mathrm{a}$ & 0.026 & $\mathrm{a}$ & $0.126 \mathrm{a}$ & $0.066 \mathrm{a}$ & $0.024 \mathrm{a}$ & $0.090 \mathrm{a}$ \\
\hline Bivoltine & $0.079 \mathrm{a}$ & 0.012 & $\mathrm{~b}$ & $0.028 \mathrm{a}$ & 0.026 & $\mathrm{a}$ & $0.056 \mathrm{~b}$ & $0.040 \mathrm{~b}$ & $0.018 \mathrm{~b}$ & $0.073 \mathrm{~b}$ \\
\hline Check & $0.077 \mathrm{a}$ & 0.008 & $\mathrm{~b}$ & $0.024 \mathrm{a}$ & 0.031 & $\mathrm{a}$ & $0.052 \mathrm{~b}$ & $0.029 \mathrm{c}$ & $0.014 \mathrm{c}$ & $0.040 \mathrm{c}$ \\
\hline \multicolumn{11}{|l|}{ Inbred lines } \\
\hline A 619 & $0.096 \mathrm{bc}$ & 0.016 & $a b$ & $0.022 \mathrm{a}$ & 0.019 & $\mathrm{a}$ & $0.031 \mathrm{a}$ & $0.029 \mathrm{a}$ & $0.012 \mathrm{a}$ & $0.067 \mathrm{ab}$ \\
\hline F 2 & $0.086 \mathrm{abc}$ & 0.012 & a & $0.028 \mathrm{ab}$ & 0.023 & $\mathrm{a}$ & $0.076 \mathrm{~b}$ & $0.048 \mathrm{ab}$ & $0.021 \mathrm{c}$ & $0.044 \mathrm{a}$ \\
\hline C M 107 & $0.116 \mathrm{c}$ & 0.005 & $\mathrm{a}$ & $0.035 \mathrm{~b}$ & 0.036 & $\mathrm{a}$ & $0.072 \mathrm{~b}$ & $0.048 \mathrm{ab}$ & $0.013 \mathrm{ab}$ & $0.066 \mathrm{ab}$ \\
\hline $\mathrm{C} \mathrm{M} 7$ & $0.056 \mathrm{a}$ & 0.011 & $\mathrm{a}$ & $0.019 \mathrm{a}$ & 0.036 & $\mathrm{a}$ & $0.095 \mathrm{bc}$ & $0.053 \mathrm{ab}$ & $0.025 \mathrm{~d}$ & $0.082 \mathrm{~b}$ \\
\hline A 654 & $0.088 \mathrm{abc}$ & 0.025 & $\mathrm{~b}$ & $0.028 \mathrm{ab}$ & 0.028 & $\mathrm{a}$ & $0.072 \mathrm{~b}$ & $0.031 \mathrm{a}$ & $0.025 \mathrm{~d}$ & $0.079 \mathrm{ab}$ \\
\hline CM 47 & $0.064 \mathrm{ab}$ & 0.011 & $\mathrm{a}$ & $0.032 \mathrm{~b}$ & 0.026 & $\mathrm{a}$ & $0.120 \mathrm{c}$ & $0.058 \mathrm{~b}$ & $0.016 \mathrm{~b}$ & $0.065 \mathrm{ab}$ \\
\hline
\end{tabular}

$\$$ Means followed by the same letter in the same column for the ECB infestation treatments and for the inbred lines are not significantly different at $P>0.05$ (Waller-Duncan K-ratio $t$-test)

The authors wish to thank François Meloche, Research Entomologist at the Plant Research Centre, Agriculture Canada, Ottawa, Ontario, for his valuable suggestions in the review of this manuscript.

Anglade, P., H.C. Chiang, B. Dolinka, W. Faber, D. Hadzistevic, M. Hudon, C. Kania, A. Monteagudo, A. Mustea, and I.D. Shapiro. 1972. Rapport sur le programme international d'étude écologique sur la pyrale du maïs, Ostrinia nubilalis (Hbn.), en 1969. Ann. Soc. Entomol. Qué. 17: 48-56.

Anglade, P., and cooperators. 1973. Comparative study of three characteristics used for judging the susceptibility of corn lines to Ostrinia nubilalis. International Project on Ostrinia, Agricultural Research Institute Hungarian Academy Sciences, Phase I: $48-61$.

Barry, D., and G.M. Chippendale. 1988. Evaluation of the larval inoculator for dispensing neonate maize stem borers mixed with maize cob grits. J. Kans. Entomol. Soc. 61: 357-359.

Chiang, H.C., K.C. Kim, and B.W. Brown. 1970. Morphometric variability related to ecological conditions of three biotypes of Ostrinia nubilalis (Lepidoptera: Pyraustidae) in the north central United States. Ann. Entomol. Soc. Am. 63: 1013-1016.

Guthrie, W.D. 1971. Resistance of maize to secondbrood European corn borer. Proc. Hybrid Corn Industry Res. Conf. 26: 165-179.

Guthrie, W.D., F.F. Dicke, and C.R. Neiswander. 1960. Leaf and sheath feeding resistance to the European corn borer in eight inbred lines of dent corn. Ohio Agric. Exp. Stn. Res. Bull. 860, 38 pp.
Guthrie, W.D., J.L. Jarvis, and J.C. Robbins. 1984. Damage from infesting maize plants with European corn borer egg masses and larvae. J. Agric. Entomol. 1: 6-16.

Hudon, M., and M.S. Chiang. 1975. Resistance of maize inbred lines to leaf feeding by the European corn borer, Ostrinia nubilalis (Hübner) in Quebec, Canada. International Project on Ostrinia, Agricultural Research Institute Hungarian Academy Sciences, Phase III: 73-80.

Hudon, M., and M.S. Chiang. 1985. Resistance and tolerance of maize germplasm to the European corn borer Ostrinia nubilalis (Hübner) and its maturity in Quebec. Maydica 30: 329-337.

Hudon, M., and M.S. Chiang. 1991. Evaluation of resistance of maize germplasm to the European corn borer Ostrinia nubilalis (Hübner) and relationship with maize maturity in Quebec. Maydica 36: 1-6.

Hudon, M., D. Chez, and M.S. Chiang. 1979. Resistance and tolerance of maize inbred lines to the European corn borer Ostrinia nubilalis (Hübner) and their maturity in Quebec. Phytoprotection 60: 1-22.

Kim, K.C., H.C. Chiang, and B.W. Brown. 1967. Morphometric differences among four biotypes of Ostrinia nubilalis (Lepidoptera: Pyralidae). J. Econ. Entomol. 60: 796-801.

Marston, A.R., and C.B. Dibble. 1930. Investigations of corn borer control at Monroe, Michigan. Mich. Agric. Exp. Stn. Spec. Bull. 204, 47 pp.

Martel, P., and M. Hudon. 1976. Les insectes nuisibles aux cultures maraîchères dans le sud-ouest du Québec en 1975. Ann. Soc. Entomol. Qué. 21: 75-78.

McLeod, D.G.R. 1976. Geographical variation of diapause termination in the European corn borer Ostrinia nubilalis (Lepidoptera: Pyralidae) in southwestern Ontario. Can. Entomol. 108: 1403-1408. 
McLeod, D.G.R. 1978. Genetics of diapause induction and termination in the European corn borer, $\mathrm{O} . \mathrm{nu}$ bilalis (Lepidoptera: Pyralidae) in southwestern Ontario. Can. Entomol. 110: 1351-1353.

McLeod, D.G.R., C. Ritchot, and T. Nagai. 1979. Occurrence of a two generation strain of the European corn borer, Ostrinia nubilalis (Lepidoptera: Pyralidae), in Quebec. Can. Entomol. 111: 233-236.

Mutuura, A., and E. Munroe. 1970. Taxonomy and distribution of the European corn borer and allied species: genus Ostrinia (Lepidoptera: Pyralidae). Mem. Entomol. Soc. Can. 71, 112 pp.
Neiswander, C.R. 1962. An adventure in adaptation: The European corn borer, Ostrinia nubilalis (Hübn.). Ohio Agric. Exp. Stn. Res. Bull. 916, 22 pp.

Showers, W.B. 1981. Geographic variation of the diapause response in the European corn borer. Pages 97 111 in R.F. Denno and H. Dingle (eds.). Insect life history patterns: habitat and geographic variation, Springer-Verlag, New York.

Zuber, M.S. 1975. Corn germplasm base in the U.S. is it narrowing, widening, or static? Proc. Annu. Corn Sorghum Res. Conf. 30: 277-286. 